\title{
Association of Fusarium and Phomopsis with Peroba Rosa Seeds
}

\author{
Edson José Mazarotto ${ }^{1}$ (D), Ida Chapaval Pimentel ${ }^{2}$ (D), \\ Daniela Cleide Azevedo de $\mathrm{Abreu}^{3}$ (D), Alvaro Figueredo dos Santos ${ }^{4}$ \\ ${ }^{1}$ Setor de Ciências Biológicas, Universidade Federal do Paraná - UFPR, Curitiba/PR, Brasil \\ ${ }^{2}$ Universidade Federal do Paraná - UFPR, Curitiba/PR, Brasil \\ ${ }^{3}$ Universidade Tecnológica Federal do Paraná - UTFPR, Dois Vizinhos/PR, Brasil \\ ${ }^{4}$ Centro Nacional de Pesquisas Florestais, Empresa Brasileira de Pesquisa Agropecuária - EMBRAPA, Colombo/PR, Brasil
}

\begin{abstract}
Peroba rosa (Aspidosperma polyneuron) is a native forest species endangered due to intense predatory exploitation. The objective of this study was to evaluate the association and fungi transmission in peroba rosa seeds from four regions of Paraná. Germination and vigor were evaluated using the paper roll method. Sanitary analysis consisted of the detection of endophytic and epiphytic fungi using potato-dextrose-agar medium and Fusarium selective medium. For transmission, non-disinfested seeds were sown in vermiculite and kept in greenhouse. Germination ranged from 9.3\% to 60\%. Fusarium sp. and Phomopsis sp. were found as epiphytic and also as endophytic. There was transmission of Fusarium sp. and Phomopsis sp. from seeds to seedlings, causing malformation and necrosis on roots and cotyledons.
\end{abstract}

Keywords: seed pathology, native forest seeds, endophytic fungi. 


\section{INTRODUCTION}

Peroba Rosa (Aspidosperma polyneuron Muell). Arg.) is a native forest species endangered due to intense logging and fragmentation of original natural ecosystems (IPEF; EMBRAPA, 1981). This species is found in the semideciduous seasonal forest, in montane and submontane formations (Veloso et al., 1991; Carvalho, 2004). It occurs in the Southern, Southeastern and Midwestern regions of Brazil (Rizzini, 1990; Carvalho, 2004).

Peroba rosa presents excellent quality wood, being widely used in civil and naval construction, carpentry, furniture industry and reforestation. Due to its high commercial value, the species is endangered and is on the list for ex situ and in situ conservation, in both Brazil and Venezuela (Carvalho, 2004). It was also classified as a rare species in the semideciduous seasonal forest and included in the list of endangered plants of Paraná (Hatschbach \& Ziller, 1995).

Few studies have been conducted in Brazil to determine the health and physiological quality of native forest species (Lazarotto et al., 2012). In general, seeds of these species present low germination, usually associated to the action of microorganisms that cause seed deterioration. Fungi are the main cause of diseases during seedling formation and germination (Vechiato \& Parisi, 2013).

Some studies have been carried out to determine the main pathogens associated with seeds (Lazarotto et al., 2012; Maciel et al., 2012). In Cedar (Cedrella fissilis), Lazarotto et al. (2012) observed the presence of the following fungi: Ascochyta sp., Aspergillus sp., Colletotrichum sp., Epicoccum sp., Penicillium sp., Rhizoctonia sp., Trichoderma sp., Phomopsis sp., Fusarium sp.,
Rhizopus sp., and Sphaaeropsis sp. In angico-vermelho (Parapiptadenia rigida), the following fungi were detected: Penicillium sp ., Aspergillus sp., Rhizopus sp., Epicoccum sp., Thielaviopsis sp., Cladosporium sp., Fusarium sp., Pestalotia sp., Alternaria sp., Phoma sp. and Nigrospora sp. (Maciel et al., 2012). However, there is no previous research on fungi associated with peroba rosa seeds.

In this context, this study aims to evaluate the association of fungi with peroba rosa seeds from four regions of the state of Paraná and to verify the transmission of these fungi through seeds.

\section{MATERIAL AND METHODS}

\subsection{Origin of seeds}

Lots of peroba rosa seeds come from ten municipalities of four regions of state of Paraná (Table 1) and were provided by the Federal Technological University of Paraná (UTFPR - Campus Dois Vizinhos, PR). Physiological and sanitary quality tests were developed at "Laboratório de Sementes Florestais" (Laboratory of Forest Seeds) and at "Laboratório de Patologia Florestal - Embrapa Florestas" (Laboratory of Forest Pathology), in Colombo (PR).

\subsection{Germination and vigor test}

The germination test was performed using paper roll, with 150 seeds of each origin, divided into six replicates of 25 seeds each. Seed asepsis was carried out by immersing seeds in detergent solution (five drops of neutral detergent/100 $\mathrm{ml}$ of water) for five minutes and then washing in sterile distilled water. The substrate consisted of three "germitest"

Table 1. Peroba rosa seed collected in ten municipalities of four regions of the State of Paraná.

\begin{tabular}{|c|c|c|c|}
\hline Lots & Region & Municipality & Weight of 1.000 seeds (g) \\
\hline 1 & West & Capitão Leônidas Marques & 70.3 \\
\hline 11 & & Boa Vista da Aparecida & 105.3 \\
\hline 22 & & Corbélia & 108.6 \\
\hline 3 & Southwest & Cruzeiro do Iguaçu & 97.3 \\
\hline 10 & & São Jorge do Oeste & 89.5 \\
\hline 7 & & Realeza & 97.0 \\
\hline 13 & & Nova Prata do Iguaçu & 103.5 \\
\hline $1 \mathrm{M}$ & South Central & Telêmaco Borba & 79.7 \\
\hline $8 \mathrm{CM}$ & Northwest & Terra Boa & 81.3 \\
\hline $9 \mathrm{CM}$ & & Cianorte & 83.5 \\
\hline
\end{tabular}


paper sheets: two placed on the base and the other covering the seeds. Sheets were moistened with sterile distilled water at 2.5 times the paper weight. Subsequently, the material was placed in germination Chambers at $25^{\circ} \mathrm{C}$ and continuous light for 24 hours (Brasil, 2013).

Two germination evaluations were carried out: the first germination count was performed 12 days after the test installation and the final count 26 days after test installation. The germination speed index (GSI) was determined with daily evaluations from the first day of test to stabilize germination, verifying the emission of the radicle in seeds. In the last evaluation, on the $26^{\text {th }}$ day, the shoot and radicle length was measured to complement the vigor parameters of seedlings (Vieira \& Carvalho, 1994)

\subsection{Detection and isolation of endophytic} fungi in Potato-Dextrose-Agar (PDA) and in Fusarium Selective Medium (FMS)

Seed asepsis was performed according to protocol described by Araújo et al. (2002): washing seeds in running water; immersing in $70 \%$ alcohol solution for 1 minute; immersing in $1 \%$ sodium hypochlorite solution for 4 minutes; immersing in 70\% alcohol solution for 30 seconds; rinsing twice in sterile ultrapure water.

For the detection of fungi in PDA (Santos et al., 2011) and FMS media (Anderson, 1986), 100 seeds of each lot were used for each medium, divided into 20 replicates of 5 seeds. Disinfested seeds were plated in Petri dishes with PDA medium (39g commercial potato-dextrose-agar extract, $1000 \mathrm{ml}$ ultrapure water) and FMS medium ( $15 \mathrm{~g}$ peptone, $5 \mathrm{~g}$ magnesium sulfate - $\mathrm{MgSO}_{4}, 1 \mathrm{~g}$ potassium phosphate - $\mathrm{KH}_{2} \mathrm{PO}_{4}$, $1 \mathrm{~g}$ pentachloronitrobenzene $\mathrm{PCNB}, 20 \mathrm{~g}$ agar, $1000 \mathrm{ml}$ ultrapure water, $40 \mathrm{ppm}$ chloramphenicol and $80 \mathrm{ppm}$ ampicillin).

PDA and FMS plates were incubated at $20^{\circ} \mathrm{C}$ with 12 hours light/12 hours dark photoperiod for seven days.

\subsection{Detection and isolation of epiphytic fungi in Fusarium Selective Medium (FMS)}

Seed asepsis was carried out according to the following protocol: washing seeds in running water; immersing in $70 \%$ alcohol solution for 30 seconds; immersing in $1 \%$ sodium hypochlorite solution for
1 minute; rinsing twice in sterile ultrapure water. Seeds were plated in FMS and incubated at temperature of $20^{\circ} \mathrm{C}$, with 12 hours light / 12 hours dark photoperiod for seven days.

\subsection{Test of transmission of fungi from peroba rosa seeds to seedlings}

About 100 seeds without disinfestation from each lot were used, seeded in plastic tubes with vermiculite. The material was kept in greenhouse with daily irrigation. Evaluations began 21 days after the test was installed and ended after 60 days. The number of emergent symptomatic seedlings was determined. After 60 days, seeds that had not germinated were collected and placed in humid chamber in laboratory environment for 7 days. Phytopathogenic fungi were isolated in PDA medium.

\subsection{Statistical analysis}

A completely randomized design was used. Analysis of variance (ANOVA) and Tukey's test at $1 \%$ probability were performed. All analyses were performed using ASSISTAT software 7.7 (Silva \& Azevedo, 2009).

\section{RESULTS AND DISCUSSION}

Lots with the highest germination percentage were $1 \mathrm{M}, 9 \mathrm{CM}$ and 3 , with $56.6 \%, 58 \%$ and $60 \%$, respectively, and there was no statistical difference $(\mathrm{p}<0.01)$ between lots $8 \mathrm{CM}$ and 22 (Table 2). The average germination rate reported in literature for the species ranges from $35 \%$ to $70 \%$ (Carvalho, 2004). Due to the fact that it is a native forest species, peroba rosa presents irregular germination, as observed in this study. Similar values were found by Ramos et al. (1995), which obtained $67 \%$ germination rate for peroba rosa.

In Table 2, the average seed vigor values of peroba rosa are presented. Lot $1 \mathrm{M}$ presented the highest value in the first germination count (FGC), reaching $10.5 \%$ in 12 days, not different from lot $9 \mathrm{CM}$, with $8.6 \%$. Regarding the germination speed index (GSI), the highest percentages were obtained in lots $1 \mathrm{M}, 3$, $8 \mathrm{CM}$ and $9 \mathrm{CM}$, with $11.6 \%, 11.8 \%, 10.2 \%$ and $11.7 \%$, respectively. Lot 9CM had the highest shoot length, with $66.8 \mathrm{~mm}$, while lot 22 presented the highest radicle length, $120.5 \mathrm{~mm}$, both differing only from lots 7 and 10 . 
According to Vieira \& Carvalho (1994), seeds with the highest percentage of normal seedlings in the first count, higher germination speed and higher average shoot and root length of normal seedlings are the most vigorous. However, such values are still unknown for peroba rosa.

In all seed lots, the genus Phomopsis was found as endophyte in PDA medium, whose incidence reached $65 \%$ in lot 11 (Table 3 ). There was no significant difference among lots 3, 8CM, 10 and 11. The genus Fusarium was found in $70 \%$ of seed lots, reaching $7 \%$ in lot 7 (Table 3). There was no statistical difference among lots. Other fungi found were Aspergillus, Penicillium, Rhizopus and Trichoderma.

Garzonio \& Mcgee (1983) and Hernández et al. (2015) reported that fungi of the genus Phomopsis colonize host tissues and establish relationships as endophytes, saprophytes or parasites. These fungi are associated with seeds, which are the main form of pathogen dispersal over long distances. The association of Phomopsis with seeds is evidenced by Walker et al. (2013), who verified $100 \%$ incidence of fungus in red angico seeds, and Lazarotto et al. (2012), who verified the presence of Phomopsis sp. in all samples of Cedrela fissilis seeds, which had incidence of up to $30.5 \%$. This is the first report of Phomopsis sp. associated as endophyte in peroba rosa seeds.

In FSM, Fusarium was found as endophyte only in lots 1 and $1 \mathrm{M}$, with $1 \%$ incidence (Table 3 ). There are reports of Fusarium sp. as endophyte in cowpea seeds (Vigna unguiculata), with frequency from $0.13 \%$ to $6.33 \%$ (Rodrigues \& Menezes, 2002), which is similar to values obtained for peroba rosa.

The reports on the occurrence of fungi with pathogenic potential in seeds of forest species, both internally and externally to seeds, are scarce (Nascimento et al., 2006; Santos et al., 2011).

Table 2. Germination (G), first germination count (FGC), germination speed index (GSI), shoot length (SL) and radicle length $(\mathrm{RL})$ obtained in germination and vigor tests for peroba rosa at 26 days, at $25^{\circ} \mathrm{C}$.

\begin{tabular}{cccccc|}
\hline Lots & G (\%) & FGC (12 days) & GSI (seeds/day) & SL (mm) & RL (mm) \\
\hline 1 & $26 \mathrm{~cd}^{* *}$ & $3.3 \mathrm{~cd}^{* *}$ & $5.1 \mathrm{bcd}$ & $62.5 \mathrm{abc}^{* *}$ & $95.8 \mathrm{ab}^{* *}$ \\
$1 \mathrm{M}$ & $56.6 \mathrm{a}$ & $10.5 \mathrm{a}$ & $11.6 \mathrm{a}$ & $65.7 \mathrm{ab}$ & $90.8 \mathrm{ab}$ \\
\hline 3 & $60 \mathrm{a}$ & $6.3 \mathrm{bc}$ & $11.8 \mathrm{a}$ & $60.6 \mathrm{abc}$ & $111.9 \mathrm{ab}$ \\
\hline 7 & $16.6 \mathrm{~cd}$ & $1.8 \mathrm{~d}$ & $3.16 \mathrm{~cd}$ & $50.8 \mathrm{~cd}$ & $87.3 \mathrm{~b}$ \\
\hline $\mathrm{CM}$ & $50.6 \mathrm{ab}$ & $6.5 \mathrm{bc}$ & $10.2 \mathrm{a}$ & $57.8 \mathrm{abcd}$ & $92.9 \mathrm{ab}$ \\
\hline $\mathrm{CM}$ & $58 \mathrm{a}$ & $8.6 \mathrm{ab}$ & $11.7 \mathrm{a}$ & $66.8 \mathrm{a}$ & $95.8 \mathrm{ab}$ \\
\hline 10 & $9.3 \mathrm{~d}$ & $0.1 \mathrm{~d}$ & $1.5 \mathrm{~d}$ & $52.7 \mathrm{bcd}$ & $85.3 \mathrm{~b}$ \\
11 & $18 \mathrm{~cd}$ & $0.3 \mathrm{~d}$ & $2.9 \mathrm{~cd}$ & $46.3 \mathrm{~d}$ & $101.6 \mathrm{ab}$ \\
\hline 13 & $34 \mathrm{bc}$ & $2.5 \mathrm{~d}$ & $6.1 \mathrm{bc}$ & $58.9 \mathrm{abc}$ & $114.9 \mathrm{ab}$ \\
\hline 22 & $48 \mathrm{ab}$ & $1 \mathrm{~d}$ & $8.4 \mathrm{ab}$ & $54.8 \mathrm{abcd}$ & $120.5 \mathrm{a}$ \\
\hline
\end{tabular}

${ }^{* *}$ Means followed by the same letter in columns do not differ by the Tukey test at $1 \%$ probability.

Table 3. Incidence (\%) of endophytic Fusarium spp. and Phomopsis spp. in peroba rosa seeds in PDA and FSM media at 7 days of incubation.

\begin{tabular}{|c|c|c|c|c|}
\hline \multirow{2}{*}{ Lots } & \multicolumn{2}{|c|}{ PDA } & \multicolumn{2}{|c|}{ FSM } \\
\hline & Fusarium spp. & Phomopsis spp. & Fusarium spp. & Phomopsis spp. \\
\hline 1 & $2^{\mathrm{ns}}$ & $17 c^{\star *}$ & $1^{\mathrm{ns}}$ & $0 \mathrm{~b}^{\star *}$ \\
\hline $1 \mathrm{M}$ & 0 & $23 \mathrm{bc}$ & 1 & $0 \mathrm{~b}$ \\
\hline 3 & 6 & $57 \mathrm{ab}$ & 0 & $16 \mathrm{a}$ \\
\hline 7 & 7 & $23 \mathrm{bc}$ & 0 & $13 \mathrm{ab}$ \\
\hline $8 \mathrm{CM}$ & 6 & $28 \mathrm{abc}$ & 0 & $4 \mathrm{ab}$ \\
\hline $9 \mathrm{CM}$ & 1 & $18 \mathrm{c}$ & 0 & $2 \mathrm{ab}$ \\
\hline 10 & 2 & $48 \mathrm{abc}$ & 0 & $6 \mathrm{ab}$ \\
\hline 11 & 2 & $65 \mathrm{a}$ & 0 & $3 \mathrm{ab}$ \\
\hline 13 & 0 & $25 \mathrm{bc}$ & 0 & $0 \mathrm{~b}$ \\
\hline 22 & 0 & $12 c$ & 0 & $1 \mathrm{ab}$ \\
\hline
\end{tabular}

${ }^{* *}$ Means followed by the same letter in columns do not differ by the Tukey test at $1 \%$ probability. ${ }^{\text {ns }}=$ not significant. 
The niche occupied by microorganisms and their interaction with the host are the factors that classify them into endophytic, epiphytic and phytopathogenic. There is no clear boundary among these groups, but rather a gradient (Strobel et al., 2004). Endophytic fungi tend to remain latent while the environmental conditions are favorable to them; otherwise, endophyte fungi may assume a pathogenic function (Aly et al., 2010). However, several endophytic microorganisms establish an intimate association with the host, usually mutualistic, from which the hypothesis that endophytes may exert beneficial effects on their hosts emerged (Silva \& Bettiol, 2009). Thus, while endophyte fungi obtains energy, nutrients and shelter, they protect the host against pathogens, herbivores and insects, and induce plant growth and defense mechanisms (Firáková et al., 2007; Alvin et al., 2014).

The genus Fusarium was found to be epiphytic in FSM in all seed lots, with the exception of lot 10. The fungus reached 52\% incidence in lot $8 \mathrm{CM}$ and did not differ statistically from lot 9CM (Table 4). The genus Phomopsis was found at low percentages in only five lots and reached $25 \%$ incidence in lot 22 . Other fungi found as epiphytic were Aspergillus, Penicillium, Rhizopus, Trichothecium and Trichoderma.

This is the first report of the association of fungi with peroba rosa seeds. There are reports of the Association of fungi with seeds of the family Apocynaceae with other forest hosts. There are reports of Cladosporium sp., Colletotrichum sp., Epicocum sp., Pestalotia sp., Phoma sp. and Rhizoctonia sp. associated with Aspidosperma sp. (Martins \& Faiad, 1995). In mangaba (Hancornia speciosa), the presence of Cladosporium sp., Fusarium sp., Pestalotia sp. and Rhizopus sp. was verified (Barros et al., 2004).

Fusarium spp. has been found associated with seeds of several forest species (Lazarotto et al., 2012; Maciel et al., 2012, 2013). Carneiro (1990) assessed the sanitary quality of seeds of 11 native forest species and found association of Fusarium sp. with the following species: peroba amarela (Aspidosperma ramiflorum), aroeira (Astronium urundeuva), angico-do-campo (Piptadenia macrocarpa), algaroba (Prosopis juliflora), carvoeiro (Sclerolobium paniculatum) and ipê-amarelo (Tabebuia serratifolia).

There was transmission of fungus from seeds to seedlings in all lots. Lot 1 presented $18 \%$ of symptomatic plants, followed by lots 3 and $8 \mathrm{CM}$, with $12 \%$ (Table 5). The symptoms identified were dark spots in roots, dark spots in cotyledons and seedling death. The presence of Fusarium spp. and Phomopsis spp. in symptomatic seedlings was observed.

The value for non-germinated seeds (NGS) ranged from 27\% (lot 22) to 76\% (lot 7) (Table 5). Fusarium spp. structures were observed in NGS from all lots, which reached $100 \%$ incidence in lots $3,7,8 \mathrm{CM}$ and 13 (Table 6). The lowest Fusarium incidence was verified

Table 4. Incidence (\%) of epiphytic Fusarium spp. and Phomopsis spp. in peroba rosa seeds in FSM medium at 7 days of incubation.

\begin{tabular}{ccccccccccc}
\multicolumn{1}{c}{ Lots } & $\mathbf{1}$ & $\mathbf{1 M}$ & $\mathbf{3}$ & $\mathbf{7}$ & $\mathbf{8 C M}$ & $\mathbf{9 C M}$ & $\mathbf{1 0}$ & $\mathbf{1 1}$ & $\mathbf{1 3}$ & $\mathbf{2 2}$ \\
Fusarium spp. & $2 \mathrm{c}^{* *}$ & $17 \mathrm{bc}$ & $7 \mathrm{bc}$ & $12 \mathrm{bc}$ & $52 \mathrm{a}$ & $29 \mathrm{ab}$ & $0 \mathrm{c}$ & $13 \mathrm{bc}$ & $11 \mathrm{bc}$ & $2 \mathrm{c}$ \\
Phomopsis spp & $0 \mathrm{~b}^{* *}$ & $3 \mathrm{~b}$ & $2 \mathrm{~b}$ & $0 \mathrm{~b}$ & $0 \mathrm{~b}$ & $8 \mathrm{~b}$ & $0 \mathrm{~b}$ & $0 \mathrm{~b}$ & $4 \mathrm{~b}$ & $25 \mathrm{a}$ \\
\hline
\end{tabular}

${ }^{* *}$ Means followed by the same letter in rows do not differ by the Tukey test at $1 \%$ probability.

Table 5. Emergence percentage of normal and symptomatic seedlings and non-germinated peroba rosa seeds (NGS) at 60 days of seeding in the test of fungi transmission from seeds to seedlings.

\begin{tabular}{|cccc|}
\hline Lots & $\begin{array}{c}\text { Seedlings without } \\
\text { symptoms }\end{array}$ & Seedlings with symptoms & Non-germinated seeds \\
\hline $\mathbf{1}$ & 18 & 18 & 64 \\
\hline $\mathbf{1 M}$ & 58 & 8 & 34 \\
\hline $\mathbf{3}$ & 64 & 12 & 24 \\
\hline $\mathbf{8 C M}$ & 14 & 10 & 76 \\
\hline $\mathbf{9 C M}$ & 44 & 12 & 32 \\
\hline $\mathbf{1 0}$ & 60 & 8 & 64 \\
\hline $\mathbf{1 1}$ & 33 & 3 & 57 \\
\hline $\mathbf{1 3}$ & 37 & 6 & 53 \\
\hline
\end{tabular}


Table 6. Incidence (\%) of Fusarium spp. and Phomopsis spp. on non-germinated peroba rosa seeds (NGS) in fungal transmission tests.

\begin{tabular}{|lcccccccccc|}
\hline \multicolumn{1}{c}{ Lots } & $\mathbf{1}$ & $\mathbf{1 M}$ & $\mathbf{3}$ & $\mathbf{7}$ & $\mathbf{8 C M}$ & $\mathbf{9 C M}$ & $\mathbf{1 0}$ & $\mathbf{1 1}$ & $\mathbf{1 3}$ & $\mathbf{2 2}$ \\
\hline Fusarium spp. & 56.25 & 55.88 & 100 & 100 & 100 & 84.37 & 98.43 & 94.73 & 100 & 59.25 \\
\hline Phomopsis spp. & 0 & 2.94 & 4.16 & 5.26 & 2.27 & 0 & 0 & 0 & 0 & 18.51 \\
\hline
\end{tabular}

for lot $1 \mathrm{M}$, with $55.88 \%$. These high values for NGS indicate that the presence of Fusarium sp. prevented the germination of these seeds. Such pathogen behavior, which results in the embryo death before the emergence of seedling in the substrate, configures the pre-emergence damping-off (Mafia et al., 2007). Phomopsis sp. was found in $50 \%$ of NGS lots, with maximum percentage of $18.51 \%$ incidence in lot 22 (Table 6).

There are no reports in literature about the fungus transmission from seeds to seedlings of peroba rosa. However, Benetti et al. (2009) and Lazarotto et al. (2012) observed the transmission of Fusarium sp. from seed to seedlings in cedar. Lazarotto et al. (2010) also observed Fusarium transmission from seeds to seedlings of paineira (Ceiba speciosa). Maciel et al. (2012) obtained similar results for Fusarium sp. in red angico seedlings.

The action of Fusarium explains the high NGS levels in the assessed peroba rosa seed lots. According to Carneiro (1987), Fusarium spp. may be transmitted through infected seeds during germination. This can cause damage in pre-emergence, destroying seeds, or in post-emergence, damaging plants and causing lesions in the cervix, causing plant damping-off and death. Carneiro (1987) also points out that Phomopsis causes decrease in germination and seed rot disease.

\section{CONCLUSIONS}

Fungi Fusarium spp. and Phomopsis spp. were found both as endophytes and as epiphytic in peroba rosa seeds. Fusarium spp. and Phomopsis spp. transmission from seeds to seedlings was observed, which caused pre and post-emergence damping-off.

\section{SUBMISSION STATUS}

Received: 20 apr. 2017

Accepted: 19 jan., 2018

\section{CORRESPONDENCE TO}

\section{Alvaro Figueredo dos Santos}

Centro Nacional de Pesquisas Florestais, Empresa Brasileira de Pesquisa Agropecuária - EMBRAPA, Estrada da Ribeira, Km 111, CEP 83411-000, Colombo, PR, Brasil e-mail: alvaro.santos@embrapa.br

\section{REFERENCES}

Alvin A, Miller KI, Neilan BA. Exploring the potential of endophytes from medicinal plants as sources of antimycobacterial compounds. Microbiological Research 2014; 169(7-8): 483-495. http://dx.doi.org/10.1016/j. micres.2013.12.009. PMid:24582778.

Aly AH, Debbab A, Kjer J, Proksch P. Fungal endophytes from higher plants: a prolific source of phytochemicals and other bioactive natural products. Fungal Diversity 2010; 41(1): 1-16. http://dx.doi.org/10.1007/s13225010-0034-4.

Anderson RL. A new method for assessing contamination of slash and loblolly pine seeds by Fusarium moniliforme var. subglutinans. Plant Disease 1986; 70(5): 452-453. http://dx.doi.org/10.1094/PD-70-452.

Araújo WL, Lima AOS, Azevedo JL, Marcon J, KublinckySobral J, Lacava PT. Manual: isolamento de microrganismos endofíticos. Piracicaba: ESALQ; 2002.

Barros DI, Nunes HV, Bruno RLA, Silva GC, Araújo E, Souto FM. Tratamentos antifúngicos sobre a qualidade fisiológica de sementes de mangaba. In: Palestras e Resumos do Simpósio Brasileiro de Patologia de Sementes; 2004; João Pessoa. Londrina: Abrates; 2004. 148 p.

Benetti SC, Santos AF, Medeiros ACS, Jaccoud DS Fo. Levantamento de fungos em sementes de cedro e avaliação da patogenicidade de Fusarium sp. e Pestalotia sp. Pesquisa Florestal Brasileira 2009; 58: 79-83.

Brasil. Ministério da Agricultura, Pecuária e Abastecimento. Instruções para análise de sementes de espécies florestais. Brasília: Ministério da Agricultura, Pecuária e Abastecimento; 2013. 98 p.

Carneiro JS. Testes de sanidade de sementes de essências florestais. In: Soave J, Wetzel MMVS. Patologia de sementes. Campinas: Fundação Cargill; 1987. p. 386-393. 
Carneiro JS. Qualidade sanitária de sementes de espécies florestais em Paraopeba, MG. Fitopatologia Brasileira 1990; 15(1): 75-77.

Carvalho PER. Peroba-rosa - Aspidosperma polyneuron. Colombo: Embrapa Florestas; 2004. 12 p.

Firáková S, Šturdíková M, Múčková M. Bioactive secondary metabolites produced by microorganisms associated with plants. Biologia 2007; 62(3): 251-257. http://dx.doi. org/10.2478/s11756-007-0044-1.

Garzonio DM, Mcgee DC. Comparison of seeds and crop residues as sources of inoculum for pod and stem blight of soybeans. Plant Disease 1983; 67(12): 1374-1376. http:// dx.doi.org/10.1094/PD-67-1374.

Hatschbach GG, Ziller SR. Lista vermelha de plantas ameaçadas de extinção no Estado de Paraná. Curitiba: SEMA/GTZ; 1995. 139 p.

Hernández FE, Piolli RN, Peruzzo AM, Formento AN, Pratta GR. Caracterización morfológica y molecular de una colección de aislamientos de Phomopsis longicolla de la región templada y subtropical de Argentina. International Journal of Tropical Biology and Conservation 2015; 63(3): 871-884

Instituto de Pesquisas e Estudos Florestais - IPEF; Empresa Brasileira de Pesquisa Agropecuária - EMBRAPA. Conservação de recursos genéticos de essências florestais: relatório final. Piracicaba: IPEF; 1981.117 p.

Lazarotto M, Muniz MFB, Beltrame R, Santos AF, Maciel CG, Longhi SJ. Sanidade, transmissão via semente e patogenicidade de fungos em sementes de Cedrela fissilis procedentes da região sul do Brasil. Ciência Florestal 2012; 22(3): 493-503. http://dx.doi.org/10.5902/198050986617.

Lazarotto M, Muniz MFB, Santos ÁF. Detecção, transmissão, patogenicidade e controle químico de fungos em sementes de paineira (Ceiba speciosa). Summa Phytopathologica 2010; 36(2): 134-139. http://dx.doi.org/10.1590/S010054052010000200005.

Maciel CG, Muniz MFB, Milanesi PM, Lazarotto M, Blume E, Harakawa R et al. First report of Fusarium sambucinum associated on Pinus elliottii seeds in Brazil. Plant Disease 2013; 97(7): 995. http://dx.doi.org/10.1094/ PDIS-11-12-1045-PDN. PMid:30722564.

Maciel CG, Muniz MFB, Santos AF, Lazarotto M. Detecção, transmissão e patogenicidade de fungos em sementes de angico-vermelho (Parapiptadenia rigida). Summa Phytopathologica 2012; 38(4): 323-328. http://dx.doi. org/10.1590/S0100-54052012000400009.

Mafia RG, Alfenas AC, Resende MFR Jr. Tombamento de mudas de espécies florestais causado por Sclerotium rolfsii Sacc. Revista Árvore 2007; 31(4): 629-634. http:// dx.doi.org/10.1590/S0100-67622007000400007.
Martins DA No, Faiad MGR. Viabilidade e sanidade de sementes de espécies florestais. Revista Brasileira de Sementes 1995; 17(1): 75-80. http://dx.doi.org/10.17801/0101-3122/ rbs.v17n1p75-80.

Nascimento WMO, Cruz ED, Moraes MHD, Menten JOM. Qualidade sanitária e germinação de sementes de Pterogyne nitens Tull. (Leguminosae - Caesalpinioideae). Revista Brasileira de Sementes 2006; 28(1): 149-153. http:// dx.doi.org/10.1590/S0101-31222006000100021.

Ramos A, Bianchetti A, Martins EG, Fowler JAP, Alves VF. Substratos e temperaturas para a germinação de peroba (Aspidosperma polyneuron). Colombo: Embrapa Florestas; 1995.

Rizzini CT. Árvores e madeiras úteis do Brasil: manual de dendrologia brasileira. São Paulo: Ed. Edgard Blücher Ltda; 1990. 304 p.

Rodrigues AAC, Menezes M. Detecção de fungos endofíticos em sementes de caupi provenientes de Serra Talhada e de Caruaru, Estado de Pernambuco, Brasil. Fitopatologia Brasileira 2002; 27(5): 532-537. http://dx.doi.org/10.1590/ S0100-41582002000500016.

Santos AF, Parisi JJD, Menten JOM. Patologia de sementes florestais. Colombo: Embrapa Florestas; 2011. 236 p.

Silva FAS, Azevedo CAV. Principal components analysis in the software assistat- statistical attendance. In: Proceedings of the VII World Congress on Computers in Agriculture; 2009; Reno. Orlando: American Society of Agricultural and Biological Engineers; 2009.

Silva HSA, Bettiol W. Microrganismos endofíticos como agentes de biocontrole da ferrugem do cafeeiro e de promoção de crescimento. In: Bettiol W, Morandi $\mathrm{MAB}$, editores. Biocontrole de doenças de plantas: uso e perspectivas. São Paulo: Jaguariúna; 2009. p. 276-287.

Strobel G, Daisy B, Castillo U, Harper J. Natural products from endophytic microorganisms. Journal of Natural Products 2004; 67(2): 257-268. http://dx.doi.org/10.1021/ np030397v. PMid:14987067.

Vechiato MH, Parisi JJD. Importância da qualidade sanitária de sementes de florestais na produção de mudas. O Biológico 2013; 75(1): 27-32.

Veloso HP, Rangel ALR Fo, Lima JCA. Classificação da vegetação brasileira, adaptada a um sistema universal. Rio de Janeiro: Fundação Instituto Brasileiro de Geografia e Estatística; 1991. 123 p.

Vieira RD, Carvalho NM, editors. Testes de vigor em sementes. Jaboticabal: FUNEP; 1994. 164 p.

Walker C, Maciel CG, Bovolini MP, Pollet CS, Muniz MFB. Transmissão e patogenicidade de Phomopsis sp. associadas às sementes de angico-vermelho (Parapiptadenia rígida Benth). Floresta e Ambiente 2013; 20(2): 216-222. http:// dx.doi.org/10.4322/floram.2013.008. 